Data Descriptor

\title{
Airfares Data in New Zealand Domestic Aviation Market
}

\author{
Tin H. Ho ${ }^{1,2, *(\mathbb{D}, \text { Dat T. Nguyen }}{ }^{2,3}$, Thanh Ngo ${ }^{4,5, * \mathbb{C}}$ and Tu D. Q. Le ${ }^{1,2}$ \\ 1 Institute for Development \& Research in Banking Technology, University of Economics and Law, \\ Ho Chi Minh City 70000, Vietnam; tuldq@uel.edu.vn \\ 2 Vietnam National University, Ho Chi Minh City 700000, Vietnam \\ 3 School of Finance \& Banking, University of Economics and Law, Vietnam National University, \\ Ho Chi Minh City 70000, Vietnam \\ 4 School of Aviation, Massey University, Palmerston North 4442, New Zealand \\ 5 University of Economics \& Business, Vietnam National University, Hanoi 10000, Vietnam \\ * Correspondence: tinhh@uel.edu.vn (T.H.H.); t.ngo@massey.ac.nz (T.N.)
}

check for

updates

Citation: Ho, T.H.; Nguyen, D.T.; Ngo, T.; Le, T.D.Q. Airfares Data in New Zealand Domestic Aviation Market. Sustainability 2021, 13, 8916 https://doi.org/10.3390/su13168916

Academic Editor: Lynnette Dray

Received: 13 July 2021

Accepted: 3 August 2021

Published: 9 August 2021

Publisher's Note: MDPI stays neutral with regard to jurisdictional claims in published maps and institutional affiliations.

Copyright: (C) 2021 by the authors. Licensee MDPI, Basel, Switzerland. This article is an open access article distributed under the terms and conditions of the Creative Commons Attribution (CC BY) license (https:// creativecommons.org/licenses/by/ $4.0 /)$.

\begin{abstract}
Price competition has been a growing concern of worldwide researchers and managers. In the aviation market, especially with the help from e-commerce platforms such as Expedia, TripAdvisor, and SkyScanner, airfares are now available to customers in the easiest and quickest way. It thus allows airlines to match their fares immediately and simultaneously upon any changes of their rivals, given that customer' choices are made with regard to their incomes. This study provides a dataset on domestic airfares in New Zealand that could be useful for future studies in the fields of marketing, business and economics, transportation and aviation, or management. The dataset covers 12 trunk routes and 40 secondary routes in New Zealand from 19 September 2019 to 18 December 2019, a total of 90 days. It provides a rich dataset of more than 162,000 observations regarding the airfare, departure time, arrival time, flight duration, airline, departure airport, arrival airport, transiting airport, and so on. There are possibilities to extend the dataset (e.g., in terms of flying distance, airport characteristics, and airline characteristics) to make it be valuable for future study.
\end{abstract}

Dataset: https:/ / doi.org/10.7910/DVN/JTWL5H (accessed on 25 May 2021).

Dataset License: CCO.

Keywords: price competition; Air New Zealand; Jetstar; airfare; aviation; consumers' income

\section{Introduction}

Airfare competition and airline pricing behaviours, especially between low-cost carriers (LCCs) and full-service carriers (FSCs), have been intensively analysed [1-5]. The emerging business model of social commerce (i.e., social media and e-commerce) has greatly contributed to the changes in the behaviour of customers and producers/service providers [6,7]. For instance, with the help from online platforms such as Expedia, TripAdvisor, and SkyScanner, airfares are now available to customers in the easiest and quickest way. In that situation, airlines need to match their fares immediately and simultaneously upon any changes of their rivals, given that customer' choices are made with regard to their incomes. It is therefore suggested that prices of airlines can react to each other, and thus a dataset on airfares is important for further research in the field of social commerce, marketing, and management, among others.

While studies on the New Zealand's domestic aviation market are still limited [2,8,9], its unique characteristic of being dominated by two key carriers, Air New Zealand (as a FSC) and Jetstar (as a LCC), makes New Zealand a naturally duopolistic market [10], and therefore its airfares data is also unique. Although our dataset also includes information for other smaller regional airlines in the market, by analysing this unique dataset of duopolistic airfares, researchers can extend their analyses to more complex settings such as oligopoly 
or (perfect) competition. In this sense, New Zealand's domestic aviation market and this dataset can be seen as a starting point of research for other complicated markets such as the US or Europe.

This dataset presented in this study consists the domestic airfares in New Zealand, mostly of Air New Zealand and Jetstar, for a total of 52 domestic routes. Despite the differences in market structure or network of the two airlines, it is noted that they both operate on each of those routes and the airfares can somewhat represent the competition environment between the two.

The dataset can be used by other researchers to examine the price reaction or price competition between airlines in New Zealand. It is not only useful for researchers in the fields of business and economics, transportation, and aviation, but it also provides important information for (airline) managers or marketing teams, especially in understanding consumers' behaviours. In addition, the amount of data in this dataset is good enough to be used with machine learning models—such an extension would be extremely valuable. Importantly, the dataset can still be extended by adding information such as flying distance, airport's characteristics, or airline's characteristics, and it can be of good use for future research. Furthermore, it can be used to explore price discrimination for various consumer incomes, and consumer preferences or consumer behaviours according to their incomes.

\section{Descriptions of the Dataset}

This dataset presents the domestic airfares of New Zealand's airlines (mostly of Air New Zealand and Jetstar) on their domestic routes where the airlines are supposed to compete with each other. There are four primary airports (Auckland, Christchurch, Wellington and Queenstown) and five secondary airports (Dunedin, Napier/Hastings, New Plymouth, Nelson and Palmerston North) involved in this study. Consequently, the trunk routes refer to those between the four primary airports (e.g., Auckland-Wellington) while secondary routes refer to ones between a primary airport and another secondary one (e.g., Auckland-Dunedin or Nelson-Wellington). Following the approach of [11], one-way or directional airfares have been used instead of the round-trip airfares. This helps increase the number of routes being investigated. For instance, the routes Auckland-Wellington and Wellington-Auckland are considered as two independent observations. The dataset therefore ended up with a total of 26 airport-pairs, equivalent to 52 one-way routes, of which 12 are trunk routes and 40 are secondary (see Table 1 below).

Table 1. One-way domestic routes for Air New Zealand and Jetstar.

\begin{tabular}{|c|c|c|}
\hline Type of Route & Airport-Pair & Distance $(\mathrm{km})$ \\
\hline \multirow{6}{*}{ Trunk routes } & Auckland-Christchurch & 745 \\
\hline & Auckland-Wellington & 480 \\
\hline & Auckland-Queenstown & 1024 \\
\hline & Christchurch-Wellington & 304 \\
\hline & Christchurch-Queenstown & 346 \\
\hline & Wellington-Queenstown & 641 \\
\hline \multirow{20}{*}{ Secondary routes } & Auckland-Dunedin & 1061 \\
\hline & Auckland-Napier/Hastings & 327 \\
\hline & Auckland-New Plymouth & 229 \\
\hline & Auckland-Nelson & 494 \\
\hline & Auckland-Palmerston North & 375 \\
\hline & Christchurch-Dunedin & 327 \\
\hline & Christchurch-Napier/Hastings & 576 \\
\hline & Christchurch-New Plymouth & 517 \\
\hline & Christchurch-Nelson & 251 \\
\hline & Christchurch-Palmerston North & 435 \\
\hline & Wellington-Dunedin & 631 \\
\hline & Wellington-Napier/Hastings & 270 \\
\hline & Wellington-New Plymouth & 262 \\
\hline & Wellington-Nelson & 132 \\
\hline & Wellington-Palmerston North & 129 \\
\hline & Queenstown-Dunedin & 152 \\
\hline & Queenstown-Napier/Hastings & 911 \\
\hline & Queenstown-New Plymouth & 805 \\
\hline & Queenstown-Nelson & 551 \\
\hline & Queenstown-Palmerston North & 768 \\
\hline
\end{tabular}


The dataset covers the New Zealand domestic airfares on those 52 routes from 19 September 2019 to 18 December 2019, a total of 90 days. The number of observations, i.e., airfares on a particular departure time such as 7AM, $8 \mathrm{AM}$, and so on, ranges from 836 to 2423 per day during the examined period, resulting in a rich dataset of more than 162,000 observations in total. The dataset does not only include information on the airfare but also the departure time, arrival time, flight duration, airline, departure airport, arrival airport, transiting airport, and so on. Note that information on departure time, arrival time, and flight duration are scheduled or expectation only. Table 2 presents the basic characteristics of the dataset.

Table 2. Basic characteristics of the dataset.

\begin{tabular}{cccccc}
\hline Airline & Total OBS $\mathbf{~}^{\mathbf{1}}$ & Daily OBS & Average Fare (NZ\$) & Minimum Fare (NZ\$) & Maximum Fare (NZ\$) \\
\hline Jetstar & 4667 & 51.86 & 165.10 & 32.00 & 727.00 \\
Air New Zealand & 157,431 & 1749.23 & 418.79 & 63.00 & 1364.00 \\
Others & 735 & 8.17 & 311.62 & 50.00 & 589.00 \\
Whole dataset & 162,833 & 1809.26 & 411.03 & 32.00 & 1364.00 \\
\hline
\end{tabular}

${ }^{1}$ OBS stands for observations.

\section{Methods}

Data was extracted from Expedia using the Octoparse software for all available airfares on a certain pair of New Zealand domestic airports (e.g., Auckland-Wellington) and for a certain date (e.g., 16 September 2019) assuming that it is a one-way trip for a single adult on economy class. Although it is possible to extend the searching algorithm (e.g., adult vs. kid, economy vs. business, regular vs. non-regular customer), we limited the search to the simplest form of a single adult on economy class to make the fares compatible between airlines. For example, Jetstar only provides economy class, therefore the inclusion of Air New Zealand's business class airfares does not really help understanding the airfare mechanism between the two airlines. Meanwhile, Octoparse is a user-friendly and free software but it has advanced web scraping features such as scheduled scrapping and spreadsheet data exporting. Details on Octoparse as well as its tutorials are available at https:/ / www.octoparse.com/ (accessed on 12 July 2021). Since data on Expedia is reliable, we assume that our dataset also bears the same quality.

According to the 'advance purchase discount' theory [12-14], passengers looking for cheaper tickets tend to book in advance rather than waiting until the departure date. Empirical studies such as [15-18] have further pointed out that airfares appear to be flatter before the 21-days mark and start to increase after that, suggesting that the cheapest airfares should be booked 21 days in advance. Our data collection process was therefore conducted 21 days earlier; i.e., data for 19 September 2019 (in the dataset) was collected on 29 August 2019. We further argue that airlines respond to each other's prices in a similar way across different periods; i.e., should the prices of a certain airline be cheaper or higher between 7-day and 21-day in advance, the responding principle of those prices to the other airline's prices are still the same. As such, although it would be still better to have data for other periods (e.g., 1-day in advance, 7-day in advance, or even 3-month in advance) as well as keeping track of the price evolution over time when it comes closer to the departure date, such a big project requires much more resources, such as stronger computer or longer collection times. We leave these tasks for future studies.

\section{Conclusions}

In this paper, a dataset of domestic airfares in New Zealand has been introduced. The dataset covers 52 domestic routes in New Zealand from 19 September 2019 to 18 December 2019, of which 12 are trunk routes and 40 are secondary routes. It presents not only the airfares on those routes but also a range of useful information including the departure time, arrival time, flight duration, transit status, airline, departure airport, arrival airport, transiting airport, and so on. Although the selected time span is limited, the dataset still 
covers an important event when Jetstar withdrew from some routes such as AucklandPalmerston North or Nelson-Wellington [19], which could help its users to conduct some event studies. More importantly, there are possibilities to extend the dataset.

The dataset was collected from Expedia, one of the biggest online travel meta-search engines. As such, it can provide useful information on how those e-commerce platforms and social commerce in general can affect the behaviours of both buyers and sellers. The dataset could also be used to examine the degree of price competition among airlines in New Zealand. In addition, it can be used by (airline/airport) sales managers or marketing managers to understand the consumers' behaviours in New Zealand. As a rich dataset with more than 162,000 observations, it could be used for machine learning or big data models; however, there are possibilities to extend the dataset (e.g., in terms of flying distance, airport characteristics, and airline characteristics) to make it be valuable for future study.

Author Contributions: Conceptualization, T.N.; methodology, T.N. and T.D.Q.L.; software, T.N., T.H.H. and D.T.N.; validation, T.N. and T.D.Q.L.; resources, T.H.H., D.T.N. and T.D.Q.L.; data curation, T.N. and T.D.Q.L.; writing—original draft preparation, T.H.H., D.T.N., T.N. and T.D.Q.L.; writingreview and editing, T.H.H., D.T.N., T.N. and T.D.Q.L.; supervision, T.N.; project administration, T.H.H. and D.T.N.; funding acquisition, T.H.H. and D.T.N. All authors have read and agreed to the published version of the manuscript.

Funding: This research was funded by the University of Economics and Law, Vietnam National University, Ho Chi Minh City, Vietnam.

Institutional Review Board Statement: Not applicable.

Informed Consent Statement: Not applicable.

Data Availability Statement: This dataset is available for download at https://doi.org/10.7910/ DVN/JTWL5H (accessed on 12 July 2021).

Conflicts of Interest: The authors declare no conflict of interest. The funders had no role in the design of the study; in the collection, analyses, or interpretation of data; in the writing of the manuscript; or in the decision to publish the results.

\section{References}

1. Fageda, X.; Jiménez, J.L.; Perdiguero, J. Price rivalry in airline markets: A study of a successful strategy of a network carrier against a low-cost carrier. J. Transp. Geogr. 2011, 19, 658-669. [CrossRef]

2. Hazledine, T. Price discrimination in Australasian air travel markets. N. Z. Econ. Pap. 2011, 45, 311-324. [CrossRef]

3. Bilotkach, V.; Gaggero, A.; Piga, C. Airline pricing under different market conditions: Evidence from European Low-Cost Carriers. Tour. Manag. 2015, 47, 152-163. [CrossRef]

4. Zhang, Y.; Sampaio, B.; Fu, X.; Huang, Z. Pricing dynamics between airline groups with dual-brand services: The case of the Australian domestic market. Transp. Res. Part A Policy Pract. 2018, 112, 46-59. [CrossRef]

5. Hazledine, T. Legacy carriers fight back: Pricing and product differentiation in modern airline marketing. J. Air Transp. Manag. 2011, 17, 130-135. [CrossRef]

6. Chen, J.; Shen, X.-L. Consumers' decisions in social commerce context: An empirical investigation. Decis. Support Syst. 2015, 79, 55-64. [CrossRef]

7. Hajli, N.; Associate, N.H. Social commerce and the future of e-commerce. Comput. Hum. Behav. 2020, 108, 106133. [CrossRef]

8. Gillen, D.; Hazledine, T. The economics and geography of regional airline services in six countries. J. Transp. Geogr. 2015, 46, 129-136. [CrossRef]

9. Gillen, D.; Hazledine, T. Pricing of Regional Airline Services in Australia and New Zealand, 2011-2015. Econ. Pap. A J. Appl. Econ. Policy 2016, 35, 87-98. [CrossRef]

10. Henderson, I.L.; Tsui, K.W.H.; Ngo, T.; Gilbey, A.; Avis, M. Airline brand choice in a duopolistic market: The case of New Zealand. Transp. Res. Part A Policy Pract. 2019, 121, 147-163. [CrossRef]

11. Luttmann, A. Evidence of directional price discrimination in the U.S. airline industry. Int. J. Ind. Organ. 2018, 62, 291-329. [CrossRef]

12. Gale, I.L.; Holmes, T.J. The efficiency of advance-purchase discounts in the presence of aggregate demand uncertainty. Int. J. Ind. Organ. 1992, 10, 413-437. [CrossRef]

13. Dana, J.J.D. Advance-Purchase Discounts and Price Discrimination in Competitive Markets. J. Political Econ. 1998, 106, 395-422. [CrossRef] 
14. Hotle, S.L.; Castillo, M.; Garrow, L.A.; Higgins, M.J. The impact of advance purchase deadlines on airline consumers' search and purchase behaviors. Transp. Res. Part A Policy Pract. 2015, 82, 1-16. [CrossRef]

15. Etzioni, O.; Tuchinda, R.; Knoblock, C.A.; Yates, A. To buy or not to buy: Mining airfare data to minimize ticket purchase price. In Proceedings of the 9th ACM SIGKDD International Conference on Knowledge Discovery and Data Mining, Washington, DC, USA, 24-27 August 2003; pp. 119-128. [CrossRef]

16. Alderighi, M.; Cento, A.; Piga, C.A. A case study of pricing strategies in European airline markets: The London-Amsterdam route. J. Air Transp. Manag. 2011, 17, 369-373. [CrossRef]

17. De Roos, N.; Mills, G.; Whelan, S. Pricing Dynamics in the Australian Airline Market. Econ. Rec. 2010, 86, 545-562. [CrossRef]

18. CheapAir. 2021 Annual Airfare Study: Best Time to Buy Airline Tickets. Available online: https://www.cheapair.com/blog/thecheapair-2021-annual-airfare-study-domestic-flights $/$ ? unapproved=788542\&moderation-hash=146048b594e932ed7c8deacd7 a0e77f3\#comment-788542 (accessed on 12 July 2021).

19. Jetstar. Jetstar Confirms Withdrawal from Five Regional Domestic Routes in New Zealand. Available online: https://newsroom. jetstar.com/jetstar-confirms-withdrawal-from-five-regional-domestic-routes-in-new-zealand/ (accessed on 12 July 2021). 